\title{
Water Quality Analysis of Kelekar River in Burai Village Kecamatan Tanjung Batu/ Tanjung Batu Subdistrict Kabupaten Ogan Ilir/ Ogan Ilir District to Identify the Toxic Effects Caused
}

\author{
RA. Hoetary Tirta Amallia \\ ${ }^{1}$ Study Program Biology Faculty of Science and Technology, UIN Raden Fatah Palembang \\ email: taryardiansyah@yahoo.co.id
}

\section{Article Info}

Key word:

Contamination,

Toxic effects

\section{Article history:}

Submitssion: 01-11-2018

Accepted: 27-02-2019

\begin{abstract}
Water is one of the biggest components from environment and an important aspect of living organism. The source of water that can be used by community to fulfill their needs is river water, but in recent years, the river water is no longer clear. There are various kinds of water pollution/ contamination sources, including waste from community whether it is from household waste or agriculture waste in smaller to bigger scales, or also industrial waste that can cause environmentbased diseases such as cholera, dysentery, skin-disease, typhus, and so on that originated from dirty water Furthermore, if the river water has been contaminated with chemicals, especially heavy metals, it can cause severe toxic effects that will lead to death. Therefore, the aim of this research are knowing the quality of river water on Burai Village, Tanjung Baru Subdistrict, Ogan Ilir District, and analyzing the toxic effects that will occur due to the pollution/ contamination. Water examination was conducted in Laboratory of BTKL Palembang and Laboratory of Science and Technology Faculty UIN Raden Fatah Palembang. From the results of examination, it was found that physically the water was colored, smelly, and turbid, also the existance of heavy metals and numbers of high coliform, around $>1600 / 100 \mathrm{~mL}$ samples. This is very dangerous because it can contaminate the aquatic biota in the river and the community whose consuming it can lead to disease or even heavy metal poisoning.
\end{abstract}

Copyright C 20XY Universitas Islam Negeri Raden Fatah Palembang. All Right Reserved

\section{Introduction}

Environment is the most important thing in organism ecosystem because the life of organism is highly dependent from resources that produced by environment. In public health context, environmental health is an substantive that aiming community to understand one of the health problems exist in 
community (Achmadi, 2012) (Brotowidjoyo D.M.D dan Tribowo, 1995). Human life is very dependent to environment circumstances. Environmental carrying capacity is the ability of nature to support human life, must be maintained well so it can give maximal supports to human life. Water is one of the biggest components from environment and an important aspect of living organism. The source of water that can be used by community to fulfill their needs is river water (Situmorang, 2012) (Ali, 2008). However, in recent years, river water is no longer clear. Not only turbid and brownish, it even turn blackish, it sometimes smells bad. Changed in color and smell of it caused by entering of pollution or other chemicals from industrial waste leading to polluted river. The pollution of river water also caused by bad habits and negligence of humans who often dispose garbage to river or other household waste such as detergent water which is thrown away after washing (Sastrawijaya, 2009) (Wardhana, 2004). The existence of microorganisms in water are very dangerous for person who use the water because it is vulnerable to give many kinds of diseases. Most of the diseases that occur in community are environmental-based diseases such as cholera, dysentery, skin disease, typhus, and so on that originated from dirty water. Furthermore, if the river water has been polluted with chemicals, especially heavy metals, it can cause severe toxic effects that will lead to death. Therefore, the aim of this research are knowing the quality of river water on Burai Village, Tanjung Baru Subdistrict, Ogan Ilir District, and analyzing the toxic effects that will occur due to the pollution (Budiman, 2006) (Widiyanti, 2004) (Pall, 2013)

\section{Materials and Methods}

\section{Research Design}

This research is an analytical descriptive study using pure experimental methods because it identifies the water quality of the river water in Burai Village, Tanjung Batu Subdistrict, Ogan Ilir District by conducting laboratory tests, analyzing, and identifying toxic effects on the environment and surrounding communities.

\section{Population and Sample}

The samples of research are water from Kelekar river in Burai Viilage, Tajung Batu Subdistrict, Ogan Ilir District, and its community. The determination of sample collection points is done by separating the research area to segments or points that hopefully representing the research population. The determination of river water quality collection points is based on ease of access, cost, and time in research.

\section{Material and Method}

Materials that used in this research including water of Kelekar river in Desa Burai, Tanjung Batu Subdistrict, Ogan Ilir District, water sample is used to see concentration of water quality, while the parameter of water quality that measured are the parameters of physical, chemical, and biological, that has been examined in Laboratory of BTKL Palembang and Laboratory of Science and Technology Faculty UIN Raden Fatah Palembang and sample work procedures is done correspondently with SNI.

\section{Data Analysis}

Data analysis is the process of reviewing and searching for meaning from the data for finding the answer from research problems. Data analysis carried out included analysis of water quality and levels of water pollution and analysis of toxic effects that will be generated on 
surrounding ecosystem. Data is served in form of frequency distribution table. Then a theoretical approach is taken for analyzing the toxic effect caused.

\section{Results and Discussions}

\section{Physical Parameters}

The results from physical quality examination of river water as followed in determined points:

Table 1 Results Parameters of Water Physics Quality Examination

\begin{tabular}{cccc}
\hline \multirow{2}{*}{ Examination } & \multicolumn{3}{c}{ Sample Code } \\
\cline { 2 - 4 } & $\mathbf{A 1}$ & $\mathbf{A 2}$ & $\mathbf{A 3}$ \\
\hline Color & Turbid yellow & Turbid yellow & Turbid yellow \\
Taste & Plain/tasteless & Plain/tasteless & Plain/tasteless \\
Smell & Smelly & Smelly & Smelly \\
\hline
\end{tabular}

In the table above, it showed the changes of river water physics that can be seen the changes of water color became turbid yellow and smelly, where the normal physical parameter of water is no color, no smell, and tasteless. The color of waters causes by organic and inorganic substances; cause of the presence of plankton, humus, and metal ions (for example: iron and manganese), also other substances. The presence of iron oxide causes water to turn reddish, while manganese oxide causes water to turn brownish or blackish. (Hefni, 2003) (Ratnaningsih, 2010). The smell is an indication of waste water decomposition. Industrial liquid waste potentially consists smell substance or substance that potentially produces smell along the liquid waste processing (Suharno, 2012).

Entering waste into water can generate unpleasant smell and taste. Source of smell in water can be formed in gas or other chemicals from industrial waste. Many kinds of waste that contain certain chemical compounds emit specific odor (Situmorang, 2012). From the field survey results, water turbidity caused by polluting from household waste and sugar factory alongside river flow. Physically, rivers are mainly polluted with waste from household and numbers of latrine" that still used and according to the explanation from local residents, river water start getting turbid since the establishment of sugar factory in their subdistrict area. Turbidity indicates optic characteristics of water which results in light refraction into water. Turbidity is caused by the presence of certain substances which disperse such as microorganism, clay mud, or others floating thing. Turbidity will prevent the entering of light into water which is needed by living organism to photosynthesize (Salmin, 2005).

\section{Chemical Parameters}

The results from chemical quality examination of river water as followed in determined points:

Table 2 Results Parameters of Water Chemical Quality Examination

\begin{tabular}{|c|c|c|c|c|c|c|}
\hline \multirow{2}{*}{ Parameter } & \multirow{2}{*}{ Unit } & \multicolumn{4}{|c|}{ Results } & \multirow{2}{*}{$\begin{array}{l}\text { Allowed } \\
\text { number }\end{array}$} \\
\hline & & A1 & A2 & A3 & Average & \\
\hline Temperature (in Laboratory) & ${ }^{0} \mathrm{C}$ & 31 & 32 & 32 & 31,66666667 & Deviasi 3 \\
\hline Total Dissolved Solid (TDS) & $\mathrm{mg} / \mathrm{L}$ & 30 & 31 & 48 & 36,33333333 & 1000 \\
\hline
\end{tabular}




\begin{tabular}{|c|c|c|c|c|c|c|}
\hline Total Suspensed Solid (TSS) & $\mathrm{mg} / \mathrm{L}$ & 13,2 & 10,8 & 14,2 & 12,73333333 & 50 \\
\hline pH (In Laboratory) & $\#$ & 5,52 & 5,53 & 5,7 & 5,583333333 & $6,5-8,5$ \\
\hline$(\mathrm{Fe})$ & $\mathrm{mg} / \mathrm{L}$ & 0,06 & 0,07 & 01.55 & 0,07 & 0,3 \\
\hline Cadmium & $\mathrm{mg} / \mathrm{L}$ & $<0,0015$ & $<0,0015$ & $<0,0015$ & $<0,0016$ & 0,01 \\
\hline Lead/Plumbum $\quad(P b)$ & $\mathrm{mg} / \mathrm{L}$ & 0,01 & 0,01 & 0,01 & 0,01 & 0,03 \\
\hline Nitrate, as $\mathrm{N}\left(\mathrm{NO}_{3}\right)$ & $\mathrm{mg} / \mathrm{L}$ & 3,07 & 3,8 & 3,6 & 3,49 & 10 \\
\hline Nitrite, as $\mathrm{N}\left(\mathrm{NO}_{2}\right)$ & $\mathrm{mg} / \mathrm{L}$ & 0,028 & 0,013 & 0,016 & - & 0,06 \\
\hline $\begin{array}{l}\text { Biochemical Oxygen Demand } \\
(B O D)\end{array}$ & $\mathrm{mg} / \mathrm{L}$ & 1,33 & 0,73 & 1,32 & 1,126666667 & 2 \\
\hline $\begin{array}{l}\text { Chemical Oxygen Demand } \\
(C O D)\end{array}$ & $\mathrm{mg} / \mathrm{L}$ & 4 & 2 & 4 & 3,333333333 & 10 \\
\hline Dissolved Oxygen $\quad(D O)$ & $\mathrm{mg} / \mathrm{L}$ & 2,8 & 2,5 & 2,5 & 2,6 & 6 \\
\hline Cuprum & $\mathrm{mg} / \mathrm{L}$ & $<0,003$ & $<0,003$ & $<0,003$ & $<0,003$ & 0,02 \\
\hline $\begin{array}{l}\text { Water hardness } \\
(\mathrm{CaCO})\end{array}$ & $\mathrm{mg} / \mathrm{L}$ & 212,1 & 178,5 & 180,6 & 190,4 & - \\
\hline
\end{tabular}

From the results above, mainly showed the chemicals parameter based on normal value still fulfilling the terms according to Peraturan Menteri Lingkungan Hidup Nomor 50 tahun 2014. However, based on Permenkes No. 32 tahun 2017, heavy metal such lead(plumbum) should not be more than $0,05 \mathrm{mg} / \mathrm{L}$, in short, the sample of river water in Burai Village is already polluted by lead(plumbum) and other heavy metals which should no be there. Heavy metal is a chemical element which has density more than $5 \mathrm{~g} / \mathrm{cm} 3$, located in right bottom corner in periodic system of elements, has high affinity with $S$ and usually numbered of atom from 22 to 92 , from period of four to seven (Ernawati, 2001) (Hefni, 2003). Heavy metal is a dangerous polluted compound because it is toxic. If is accumulated in a huge number, can affects ecological aspect and even biological water aspect. According to Panjaitan, factors that cause the heavy metal classified as polluted substance because it has non-degradable characteristic and easily absorbed. Some heavy metals that enter the environment will be absorbed into the soil (sediments) and some will enter the river flow system which will then be carried into the sea.
Heavy metals that enter the marine ecosystem will settle into the bottom of the water and be absorbed in sediments. Heavy metals that settle on the bottom of the water will form sedimentation and it will cause marine biota that finding food on the bottom of water such as shrimps, shells, and crabs will have a chance to be contaminated with heavy metals. If marine ecosystem has been contaminated with heavy metals is consumed in certain period of time can become a toxic substance that will poison the body of living things (Palar, 2008) (Hamuda, 2012).

Beside the heavy metal pollution, from the result above also knows the value of water hardness is high enough. Water hardness divided into two types, are temporary hardness and noncarbonate hardness (permanent). Temporary hardness caused by presence of Calcium and Magnesium Bicarbonate that has been eliminated by heating up the water until it boiling or by giving Chalk into water. In the other side, noncarbonate hardness (permanent) is caused by Sulfate and Carbonate, Chloride and Nitrate from Magnesium and Calcium. Calcium that has concentration less than $75 \mathrm{mg} / \mathrm{L}$ can lead to brittle bone disease, 
while the concentration more than 200 $\mathrm{mg} / \mathrm{L}$ can lead to corrosivity on water pipes. In a smaller number of Magnesium is needed by body for bone growth, but in concentration more than $150 \mathrm{mg} / \mathrm{L}$ can induce nausea (Wardhana, 2004) (Sutrisno, 2004).

\section{Biological Parameters}

The results from Biological quality examination of river water as followed in determined points:

Table 3 Results Parameters of Water Biological Quality Examination

\begin{tabular}{ccc}
\hline Sample & Number Results of Coliform/ Colifecal & Interpretation \\
\hline A1 & $>1600$ Microorganisms $/ 100 \mathrm{ml}$ Sample & Not Eligible \\
A2 & $>1600$ Microorganisms $/ 100 \mathrm{ml} \mathrm{Sample}$ & Not Eligible \\
A3 & $>1600$ Microorganisms $/ 100 \mathrm{ml}$ Sample & Not Eligible \\
\hline
\end{tabular}

Based on the examination result above, knowing the numbers of coliform in water of Kelekar river, Burai Village, Tanjung Batu Subdistrict are very high, that around more than 1600 microorganisms/100 $\mathrm{mL}$ sample, in related to Peraturan Menteri Lingkungan Hidup Nomor 50 tahun 2014 for allowed numbers for standard quality of river water is 200 microorganisms $/ 100 \mathrm{~mL}$ sample. Yet according to Permenkes No. 32 tahun 2017 concerning Environmental Health Quality Standards and Requirements Water health should not be more than $130 \mathrm{CFU} / 100 \mathrm{ml}$ samples. Moreover, for drinking water quality standards by Permenkes Nomor 492 Nomor 90 concerning Water Quality Requirements, the numbers of coliform are zero or may not exist for drinking water.

Coliform is a bacterium that is used as an indicator of water pollution by feces transmitted by pathogenic bacteria (Chan Pelczar, 2007). The presence of microorganisms in water become one of the biological parameters that can determine the quality of water. The presence of Coliform bacterium and E.coli showed a low level of sanitation (Harley, 2002).

These bacteria represent the pollution by human feces and other warm-blooded animals, also easily detected. If this indicated bacteria found in the water, it means the water has polluted by feces bacterium also has a chance in containing pathogenic bacterium. The highet level of contamination of coliform bacterium, the higher risk of other pathogenic bacteria presence that normally lives in human feces and animals. One example if pathogenic bacterium that may presence in water contaminated by human feces or warm-blooded animal is Shigella, is microbe causing diarrhea symptom, fever, stomach cramps, and vomiting (Shehane, 2005) (Wheeler, 1993). Beside diarrhea, other diseases caused by Escherichia coli is urinary tract infections, pneumonia, meningitis in newborns, and wound infections especially wounds inside the abdomen (Jawetz, 2005) .

\section{Conclusions}

From research results that has been done in Kelekar river Burai Village Tanjung Batu Subdistrict Ogan Ilir District concerning river water quality, can be concluded as:

a. Physical quality of river water does not meet the requirements

b. Biological quality of river water does not meet the requirements indicated by 
the coliform number which exceeds the maximum allowed.

c. Chemical quality of water does not meet the requirements because heavy metal is founded.

d. Toxic effects that will be caused from Kelekar Ri ver Burai Village Tanjung batu Subdistrict Ogan Ilir Distrct is a threat of extinction for marine biota, heavy metal contamination on river biota and if consumed by human, it will be accumulated inside the body that can lead to death in certain dosage, and cause environmentalbased diseases like dysentery and diarrhea in community that still using river water which has a high number of coliform.

\section{Refrence}

Achmadi, U. F. (2012). Dasar-Dasar Penyakit Berbasis Lingkungan. Jakarta: Rajawali Pers.

Ali, M. (2008). Estimation of Surabaya River Water Quality Using Kalman Filter Algorithm. IPTEK The Journal For Technology and Science Vol 13, 3.

Brotowidjoyo D.M.D dan Tribowo, E. (1995). Pengantar Lingkungan Perairan dan Budidaya Air. Yogyakarta: Liberty.

Budiman, C. (2006). Pegantar Kesehatan Lingkungan. Jakarta: EGC.

Chan Pelczar, M. J. (2007). Elements of Microbiology. New York: Mc Graw Hill Book Company.

Ernawati, S. S. (2001). Pemasaran Industri Jasa Kesehatan. Yogyakarta: CV Andi Offset.

Hamuda, H. E. (2012). Ecological Monitoring of Danube Water Quality in Budapest Region. AmericanJournal Environmental Science, 202-211.
Harley, J. (2002). Laboratory Exercise in Microbiology. USA: The McGraw - Hill.

Hefni, E. (2003). Telaah Kualitas Air. Yogyakarta: Kanisius.

Jawetz, E. (2005). Mikrobiologi Kedokteran Edisi XXII. Jakarta: Salemba Medica.

Palar, H. (2008). Pencemaran dan toksikologi Logam Berat. Jakarta: Rieneka Cipta.

Pall, E. e. (2013). Human Impact on The Mocrobiological Water Quality of The Rivers. Journal of Medical Micribiology, 1635-1640.

Ratnaningsih, D. (2010). Implementasi Metode Storet Terhadapt Kualitas Air Sungai di Indonesia. Ecolab, $1-54$.

Salmin. (2005). Oksigen Terlarut (DO) dan Kebutuhan Oksigen Biologi (BOD) Sebagai Salah Satu Indikator Untuk Menentukan Kualitas Perairan. Jurnal Oseana, 21-26.

Sastrawijaya, T. (2009). Pencemaran Lingkungan. Jakarta: Rineka Cipta.

Shehane, S. (2005). The Influene of Rainfall On Incidence of Microbnt Sourcesl Faecal Indicators and The Dominant Sources of Fecal Pollution inFlorida River. Journal of Applied Microbiology, 11271136.

Situmorang, M. (2012). Kimia Lingkungan. Medan: Universitas Negeri Medan.

Suharno, A. d. (2012). Dasar-Dasar Teknologi Pengolahan Air Limbah. Yogyakarta: Gosyen Publishing. 
Sutrisno, T. (2004). Teknologi

Penyediaan Air Bersih. Jakarta:

Rineka Cipta.

Wardhana, W. (2004). Dampak

Pencemaran Lingkungan.

Yogyakarta: Andi.

Wheeler, V. d. (1993). Mikrobioogi

Dasar I. Jakarta: Erlangga.

Widiyanti, N. d. (2004). Analisis

Kualitatif Bakteri Koliform Pada

Depot Air Minum Isi Ulang

diKota Singaraja Bali. Jurnal

Ekologi Kesehatan, 64-67. 